\title{
Metallothionein-2A (rs1610216\&rs28366003) gene polymorphisms and the risk of stomach adenocarcinoma
}

\author{
Mohammad SHOKRZADEH ${ }^{1}$, Abbas MOHAMMADPOUR ${ }^{2}$, Nasrin GHASSEMI-BARGHI ${ }^{1}$, Vahid HOSEINI ${ }^{3}$, \\ Saied ABEDIANKENARI ${ }^{3}$ and Yahya Saleh TABARI ${ }^{1}$
}

\begin{abstract}
Background - Gastric cancer is the fourth most common cause of worldwide cancer. Also in contrast to the huge advances in curing, the chance of living is very low even in surgery cases. Having a genetic predisposition plays an important role in cancer development. The association between Metallothionein-2A gene polymorphisms and the risk of adenocarcinoma has been widely studied, yet there is only one study on stomach diseases. Objective - In this study, we aimed to investigate the association between 2 (MT-2A) polymorphisms and adenocarcinoma. Methods - This cross-sectional case control study was performed between Mach 2014 and January 2015 at the Tuba Hospital of Sari, Iran. Peripheral blood samples were collected in EDTA tube. DNA extraction was performed using the spin column procedure. The MT-2A polymorphisms MT-2A (rs1610216), (rs28366003) were determined by polymerase chain reaction-restriction fragment length polymorphism analysis in 95 a topic adenocarcinoma patients and 90 healthy individuals from Iranian population. Results - The MT-2A rs1610216 polymorphism increased the risk of adeno carcinoma in our Iranian population [OR: 3.8533; 95\%CI, 1.3155-11.2869; $P=0.0139$ ] and rs28366003 [OR: 4.0978; 95\%CI, 1.2521-13.4108; $P=0.0197$ ]. Conclusion The MT-2A gene polymorphism was associated with the risk of adenocarcinoma in the Iranian population.

HEADINGS - Metallothionein. Neoplasias gástricas. Genetic polymorphism. Polymorphism, restriction fragment length.
\end{abstract}

\section{INTRODUCTION}

Gastric cancer is the fourth most common cause of mortality due to malignancies around the world. Despite many advances in treatment, the survival rate of those who underwent surgical procedures is less than five years ${ }^{(1,2)}$. It is suggested that genetic sensitivity plays an important role in the progression of the gastric cancer $^{(3,4)}$. Gastric cancer has an epithelial source that is caused by genetic and environmental factors (eg exposure to chronic exposure to metals $)^{(5-7)}$.

Metallothioneins (MTs) are members of the family of low molecular weight cysteine proteins (molecular weights ranging from 500 to 14,000 daltons $)^{(8)}$. Metallothionein proteins have the ability to bind to the physiological heavy metals (zinc, cooper, selenium) and non-physiological heavy ions (cadmium, mercury, silver, arsenic), using the thiol group of the cysteine amino acids (Cystine amino acid consist about $30 \%$ of the amino acid content of the metallothionein proteins) ${ }^{(9)}$. They exist in all living organisms and accumulate in the membrane of the golgi apparatus ${ }^{(10)}$.

MTs have multiple cellular functions including the protection against the heavy metal toxicity, adjustment and absorption of physiological heavy fluorides, aid in the transport and disposal of heavy metals, metabolism of essential metals, immune response and protection against oxidative stress ${ }^{(6,11)}$. The four main groups of MTs are expressed in humans, which include MT4, MT3, MT2,
MT1, each of which contains several subgroups ${ }^{(12,13)}$. The levels of MTs vary in different tissues. MT3 is expressed mainly in neural, heart, renal, gastric, and tongue cells ${ }^{(2,14,15)}$. MT4 is seen only in some epithelial cells ${ }^{(16)}$. MT1, MT2A is extensively expressed in the tissues, and MT2A seems to be more expressed than MT1 $1^{(17)}$.

The expression of MTs can be $\mathrm{c}$ by several stimuli factors such as exposure to flask, oxidative stress, glucocytocoids and gene polymorphism $^{(18)}$. The response to these stimuli also depends on the MT gene. Since MTs play important roles in regulating over-the-counter factors, toxicity related to heavy metals, etc., then malfunctioning or disturbances in the expression of MTs results in the lack of controlling the cells and eventually cancer ${ }^{(19-21)}$.

Previous studies have been shown to increase or decrease the expression and polymorphism of MTs in some cancers, such as the kidney, liver, lung, prostate, mouth and skin. The most common form of human genetic differences is single nucleoid polymorphisms (SNPs), and they may play an important role in individual allergies $^{(22)}$. Single-nucleotide polymorphism is a change in just one base of DNA. These single-nucleotide variations cause different phenotypes, predisposing to or susceptibility to certain diseases ${ }^{(23)}$. Regarding the high prevalence of non-surgical advanced gastric adenocarcinomas and the low response of patients to conventional treatments (surgery, radiotherapy chemotherapy) in Mazandaran and also due to the role of MT-2A subtype (MT2A) polymorphism in the development of cancer we decide to evaluate this issue.

Declared conflict of interest of all authors: none

Disclosure of funding: no funding received

${ }^{1}$ Pharmaceutical Research Center, Department of Toxicology and Pharmacology, Faculty of Pharmacy, Mazandaran University of Medical Sciences, Sari, Iran. ${ }^{2}$ Gastrointestinal Cancer Research Center, Mazandaran University of Medical Sciences, Sari, Iran. ${ }^{3}$ Professor, Immunogenetics Research Center, Mazandaran University of Medical Sciences, Sari, Iran.

Corresponding author: Yahya Saleh Tabari. Email: ysalehtabari5336@gmail.com 
In this study, the polymorphism of the $\mathrm{C}>\mathrm{T}$ region of the nucleotide position 609 of the MT-2A gene induced the transfer of C-to-T into codon 187, the exon of six proline amino acids to the serine $^{(24-26)}$, and also the region $\mathrm{G}>\mathrm{A}$ polymorphism in $\mathrm{rs} 28366003$ the nucleotide $\mathrm{G}$ mutant has been replaced by an ancestral nucleotide A, in which the genomic DNA extracted from peripheral blood leucocytes in patients with gastric cancer and healthy subjects was investigated. Identifying genetic polymorphisms in people with gastric cancer, in addition to helping to recognize the mechanism of the disease, is effective in identifying and screening people who are prone to illness and as a result of their prevention.

\section{METHODS}

This case-control study was performed on 95 patients with gastric cancer who referred to the Toba Clinic, Mazandaran University of Medical Sciences, (Informed consent was taken for testing) who had no family history of gastric cancer and identified by expert physician based on the results of endoscopic and pathologic studies. Also, 90 healthy individuals matched according to age, sex, and living area of Mazandaran province were studied as control group. The genomic DNA was extracted using DynaBio extraction kit, a biochemical assay, and extracted from peripheral blood leukocytes. A spectrophotometer was used to determine the quality and amount of the extracted DNA. After examining the quality of the DNA extracted from the control and the patient samples, in the following, we mixed $2 \mu \mathrm{L}$ of the sample with $12.5 \mu \mathrm{L}$ of mastermix and $0.8 \mu \mathrm{L}$ of the relevant primers, and eventually Distilled water was dispersed in a volume of $25 \mu \mathrm{L}$ in order to to prepare the required samples for PCR (TABLE 1).

Then the polymerase chain reaction was performed using a Bio-Rad apparatus according to the initial annealing temperature program at $94^{\circ} \mathrm{C}$ for 5 minutes, secondary annealing was done at $94^{\circ} \mathrm{C}$ for 30 seconds, the primer binding temperature (rs 1610216 (58) and (rs28366003) $60^{\circ} \mathrm{C}$ for 30 seconds, initial amplification of the product at $37^{\circ} \mathrm{C}$ for 30 seconds to 36 cycles, and finally the reproduction temperature of the secondary product at $72^{\circ} \mathrm{C}$ for 10 minutes (TABLE 2). After polymerase chain reaction to ensure reproduction, the product was applied to $1 \%$ agarose gel using TBE solution at test temperature The apparent and $100 \mathrm{mV}$ voltage created using the power lab Bio-Rad device was electrophoresed in the vicinity of the marker, then, they were stained using ethidium bromide, and identified using a dye gel device.

After observing the desired fragment, $8 \mu \mathrm{L}$ of PCR product (rs1610216) $\mathrm{C}>\mathrm{T}$ and (rs28366003) $\mathrm{G}>\mathrm{A}$ were mixed with $1 \mu \mathrm{L}$ of the enzyme $x 10$ buffer and $0.2 \mu \mathrm{L}$ of the enzyme SmaI and BsgI, respectively for enzymatic digestion of each SNP, and were finally distilled into $10 \mu \mathrm{L}$ distilled water and placed at $37^{\circ} \mathrm{C}$ for 2 hours. After the adjuvant time with the product enzyme, electrophoresis of $1.5 \%$ agarose gel was performed, then electrophoresis bands were detected and the polymorphism was detected by Doc gel method. Statistical analysis was performed using Medcalc software, the results are presented below.
TABLE 2. Temperature protocol for ThermoCycler device.

\begin{tabular}{|c|c|c|c|}
\hline Denaturing & \multicolumn{2}{|c|}{$\begin{array}{c}\text { at a temperature of } 94^{\circ} \mathrm{C} \text { for } 5 \\
\text { minutes }\end{array}$} & A single cycle \\
\hline Denaturing & \multicolumn{2}{|c|}{ at $94^{\circ} \mathrm{C}$ for 30 seconds } & \\
\hline \multirow[t]{2}{*}{ Annealing } & rs1610216 & $\begin{array}{l}\text { at a temperature of } \\
58^{\circ} \text { for } 30 \mathrm{~s}\end{array}$ & \multirow[t]{2}{*}{35 cycles } \\
\hline & rs28366003 & at $60^{\circ}$ for $30 \mathrm{~s}$ & \\
\hline Extension & \multicolumn{2}{|c|}{ at $72^{\circ} \mathrm{C}$ for 30 seconds } & \\
\hline Extension & \multicolumn{2}{|c|}{ temperature of $72^{\circ} \mathrm{C}$ for 10 minutes } & A single cycle \\
\hline
\end{tabular}

\section{Statistical analysis}

The association between cases and controls were examined by chi-square test with medcalc software. Value of $P<0.05$ was considered to be significant. Also the genotype frequencies were checked for consistency among groups.

\section{RESULTS}

This case-control study was performed on 95 patients with gastric cancer and 90 healthy individual age range of 22-90 years (TABLE 3).

TABLE 3. Questionnaire information for people with gastric cancer.

\begin{tabular}{lcc}
\hline City (number) & Man (number) & Woman (number) \\
\hline Sari (42 people) & 28 & 14 \\
Ghaemshahr (14 people) & 10 & 4 \\
Behshahr (7 people) & 5 & 2 \\
Neka (15 people) & 11 & 4 \\
Juybar (6 people) & 4 & 2 \\
Mahmoud Abad (3 people) & 2 & 1 \\
Galoogah (2 people) & 1 & 1 \\
Surk (3 people) & 2 & 1 \\
Savadkuh (3 people) & 2 & 1 \\
Total (95 people) & 65 & 30 \\
\hline
\end{tabular}

The two groups were examined for single-nucleotide polymorphism (rs1610216) $\mathrm{C}>\mathrm{T}$ and (rs28366003) $\mathrm{G}>\mathrm{A}$ in the MT2A gene, and a significant difference was observed between the polymorphism of the MT-2A gene in control and control groups [OR: 3.8533; 95\% CI, 1.3155-11.2869; $P=0.0139]$ rs 1610216 and rs28366003 [OR: 4.0978; 95\% CI, 1.2521-13.4108; $P=0.0197$ ] The distribution of genotypic and allotropic abnormalities in patients with gastric cancer and control group is summarized in sections 4 and 5.

In genotypic study conducted in this study between two groups of patients and control in polymorphism (rs28366003) MT-2, the comparison of homozygote genotype (AA) with mutant homozygous genotype $(\mathrm{GG})$ increased the risk of increase of population to patient by four times Find $(P=0.0197)$. (TABLE 4)

TABLE 1. Primer feature.

\begin{tabular}{lcccc}
\hline PCR product sequence & PCR product & Restriction Enzyme & Primer Sequence & Location \\
\hline 56608619 to 56608263 & T: $396 \mathrm{bp}$ & \multirow{2}{*}{ SmaI } & Forward: GCTAGAGTCGGGACAGGTTG & Reverse: CAGGTTCGAGTACAGGACAGG \\
& C: $268+128 \mathrm{bp}$ & & Forward: GGGGCTTTTGCACTCGTC & (rs28366003) \\
56608522 to 56608650 & A: $39+107 \mathrm{bp}$ & BsgI & Reverse: GTTGGGATCCATGGCGAG & G $>$ A \\
\hline
\end{tabular}


TABLE 4. Genotypic and Allelic Polymorphism Frequency (2836600 rs) MT-2G $>$ A

\begin{tabular}{lcccc}
\hline $\begin{array}{l}\text { Genotype / } \\
\text { Allele }\end{array}$ & $\begin{array}{c}\text { Case } \\
(\mathbf{n}=95)\end{array}$ & $\begin{array}{c}\text { Control } \\
(\mathbf{n}=90)\end{array}$ & OR $(\mathbf{9 5 \%}$ CI $)$ & $* \boldsymbol{P}$-value \\
\hline AA & 44 & 52 & Ref 1.00 & - \\
GA & 39 & 34 & $1.3604(0 / 7564-2.4468)$ & 0.3041 \\
GG & 12 & 4 & $4.0978(1.2521-13.4108)$ & 0.0197 \\
AG+GG & 51 & 38 & $1.6211(0.927-2.8394)$ & 0.0902 \\
AA+GG & 56 & 56 & Ref 1.00 & - \\
AG & 39 & 34 & $1.1338(0.6429-1.9995)$ & 0.6644 \\
\hline
\end{tabular}

OR: odds ratio; CI: confidence interval. * Significant differences between cases and controls.

In the genotypic study conducted in this study between the two groups of patients and control in polymorphism (rs1610216) of MT-2, the comparison of normal homozygote genotype (TT) with homozygous mutant genotype (CC) showed that the risk of population increased to 3.8 folds $(P=0.0139)$. (TABLE 5)

Studying the prevalence of MT-2A allele gene based on chisquare test in rs28366003 $\left(P=0.1564, \mathrm{x}^{2}=2.009\right)$, also in rs1610216 $\left(P=0.2233=x^{2}=1.483\right)$, since $P$-value isn't less than 0.05 , then there is no significant difference in the distribution of MT-2A allele polymorphism between the two patient and control groups.

TABLE 5. Genotypic and Allelic Polymorphism Frequency (rs1610216) $\mathrm{MT}-2 \mathrm{C}>\mathrm{T}$

\begin{tabular}{lcccc}
\hline $\begin{array}{l}\text { Genotype / } \\
\text { Allele }\end{array}$ & $\begin{array}{c}\text { Case } \\
(\mathbf{n}=95)\end{array}$ & $\begin{array}{c}\text { Control } \\
(\mathbf{n}=90)\end{array}$ & OR $(\mathbf{9 5 \%} \mathbf{C I})$ & $* \boldsymbol{P}$-value \\
\hline TT & 43 & 46 & Ref 1.00 & - \\
TC & 36 & 40 & $0.9788(0.5421-1.7672)$ & 0.0711 \\
CC & 16 & 4 & $3.8533(1.3155-11.2869)$ & 0.0139 \\
TC+CC & 52 & 44 & $1.2721(0.7297-2.2178)$ & 0.3961 \\
CC+TT & 59 & 50 & Ref 1.00 & - \\
CT & 36 & 40 & $0.7801(0.4435-1.3722)$ & 0.3887 \\
\hline
\end{tabular}

OR: odds ratio; CI: confidence interval. * Significant differences between cases and controls.

\section{DISCUSSION}

Gastric cancer is currently one of the most common cancers and the fourth leading cause of cancer deaths in the world. Due to poor prognosis, this cancer is diagnosed in advanced stages, and because of the inadequacy of conventional treatments in advanced stages, most patients, even after surgery, survive only for five years and then die. The causes of the difference in the incidence of gastric cancer are geographical differences, genetic features, individual lifestyle and associated illness. The number of deaths from stomach cancer is much lower than in previous years, but this number is still high in countries such as Japan, China, and Chile ${ }^{(27,28)}$. The cause of gastric cancer is not clear, and so many factors have been reported. Factors such as Helicobacter pylori infection, genetics, environmental factors, nutrition, alcohol, terrestrial diseases such as benign stomach polyps and chronic ulcers have been identified. The best method for identifying gastric cancer is endoscopic and pathologic studies.

Generally, normal tissues usually do not show MT expression. However, following treatment with cytokines, metal ions, or UV irradiation, expression of MT is stimulated. Besides its potential favorable effect via detoxification of metal ions, MT may also apply an antiapoptotic and mitogenic effect. New reports have demonstrated that the down-regulation of MT constrained cell growth and induced apoptosis in MCF-7 cells. This effect was related with the induction of $p 53$ and $c$-fos expression, while $c$ $m y c$ and $b c l-2$ transcripts were down-regulated. Further evidence for an antiapoptotic effect for MT was originated from studies exhibiting a certain contact between MT and the p50 subunit of $\mathrm{NF}-x \mathrm{~B}$ in MCF-7 cells, which leads to the transactivation of this transcription factor by MT, so supporting the theory that NF- $\triangle \mathrm{B}$ may mediate the antiapoptotic effects of $\mathrm{MT}^{(29,30)}$. Together, these findings support the hypothesis that MT is a growth-promoting and antiapoptotic intracellular protein that may contribute to the pathogenesis of human malignancies ${ }^{(14)}$.

Epidemiological examination has exposed that individuals with a family history of gastric cancer have a 3-fold increased risk of developing gastric cancer as compared with the unaffected population. Also, it has recently been shown that cell proliferation in the gastric mucosa of these individuals increases independent of $H$. pylori infection.

The mechanisms leading to overexpression of MT in tumor tissues are mainly unknown. It has been established by numerous groups that MT expression is induced by growth factors, cytokines, and UV irradiation. Overexpression of MT resulting from $M T$ gene amplification has been demonstrated in cell lines chronically exposed to cadmium. Furthermore, Ha-ras mutation may also lead to enhanced MT transcription ${ }^{(14,31)}$. Clonal overexpression of MT in the colon of mice treated with the mutagen dimethylhydrazine was linked to somatic mutations in the morphologically normal mucosa. In this model, it has been proposed that MT overexpression may be the consequence of cis-activating mutations of the $M T$ gene or trans-activating mutations of regulatory genes ${ }^{(31)}$.

Considering the high prevalence of gastric cancer in the north of Iran (Mazandaran) and even behind the patients even after surgery, this study was designed to investigate the association between MT-2A promoter polymorphism and gastric cancer awareness. However, genetic polymorphism can have a widespread effect in the sensitivity and spread of gastric cancer. As stated, in a study by Dong-Wang Yan (2012) on cancer cell lines using real time-PCR and immunohistochemistry, to detect multiple metallothionein isoforms, they observed that the MT1F, MT1G isoforms, MT1X and MT2A have been reduced ${ }^{(32)}$. In another study conducted by Starska et al. In Poland (2014), using a PCR-RFLP method for throat cancer, they observed that metallothionein polymorphism is involved in the development of this cancer, and they separate DNA from blood cells and then, the polymorphisms rs28366003, rs1610216 were examined for the promoter region and rs10636 for the 3'UTR region $^{(8)}$. In another report by Krześlak et al. in Poland (2014) on prostate cancer using the PCR-RFLP method, they observed that rs 28366003 polymorphism is associated with the metallothionein promoter region in the expression of the gene in metallothionein ${ }^{(33)}$, These studies are consistent with our research, which shows that factors that are involved in the development of gastric cancer such as race and people, geographical location and type of nutrition among different communities should be evaluated. So Metallothionein-2A (rs1610216\&rs28366003) gene polymorphisms can consider as a valid method for diagnosis of gastric cancer in feature.

It is suggested that in order to be more certain about the relationship between this polymorphism and gastric cancer, more SNPs of this gene and other genes should be involved and in different individuals in terms of race, geographical areas and with more people. As well as on different genetic treasures. 


\section{ACKNOWLEDGEMENTS}

Authors would like to thank all the people who participated in this research. In the Ethics Committee of Mazandaran University of Medical Sciences, it has the code IR.MAZUMS.REC.96.1211. This study was conducted with the financial support of the Research and Technology Dept. of Mazandaran University of Medical Sciences. The benefits of this research is for Mazandaran's medical sciences. The researchers are grateful to the vice president for their support.

\section{Authors' contribution}

Shokrzadeh M: study design and management. Hoseini V: perform tests. Abediankenari S and Tabari YS: perform tests. Mohammadpour A: statistical analyses. Ghassemi-Barghi N: writing article, all authors read and approve final manuscript.

\section{Orcid}

Mohammad Shokrzadeh. Orcid: 0000-0002-0071-6530.

Abbas Mohammadpour. Orcid: 0000-0003-2797-1766.

Nasrin Ghassemi-Barghi. Orcid: 0000-0002-0673-4262.

Vahid Hosseini: Orcid. 0000-0002-2303-4460.

Saeid Abediankenari. Orcid: 0000-0002-4287-2670.

Yahya Saleh Tabari. Orcid: 0000-0001-8339-1745.

Shokrzadeh M, Mohammadpour A, Ghassemi-Barghi N, Hoseini V, Abediankenari S, Tabari YS. Polimorfismos do gene metalotioneína-2A (rs1610216\&rs28366003) e o risco de adenocarcinoma de estômago. Arq Gastroenterol. 2019;56(4):367-71.

RESUMO - Contexto - O câncer gástrico é a quarta causa mais comum de câncer em todo o mundo. Também em contraste com os enormes avanços na cura, a chance de viver é muito baixa, mesmo em casos de cirurgia. Ter uma predisposição genética desempenha um papel importante no desenvolvimento do câncer. A associação entre polimorfismos do gene metalotioneína-2A e o risco de adenocarcinoma tem sido amplamente estudada, mas há apenas um estudo sobre doenças estomacais. Objetivo - Neste estudo, objetivou-se investigar a associação entre 2 (MT-2A) polimorfismos e adenocarcinoma. Métodos - Um estudo de controle de caso transversal foi realizado entre março de 2014 e janeiro de 2015 no hospital Tuba, Sari, Irã. Amostras de sangue periférico foram coletadas em tubo EDTA. A extração do ADN foi executada usando o procedimento da coluna da rotação. Os polimorfismos MT-2a MT-2A (rs1610216), (rs28366003) foram determinados pela análise do polimorfismo do comprimento do fragmento da reação-limitação de cadeia da polimerase em 95 pacientes com adenocarcinoma tópico e em 90 indivíduos saudáveis da população iraniana. Resultados-O polimorfismo MT-2A rs1610216 aumentou o risco de adenocarcinoma de em nossa população iraniana. [OR: 3,8533; 95\%CI, 1,3155-11,2869; $P=0,0139$ ] e rs 28366003 [OR: 4,0978; $95 \% \mathrm{CI}, 1,2521-13,4108 ; P=0,0197]$. Conclusão - O polimorfismo do gene MT-2A foi associado ao risco de adenocarcinoma na população iraniana.

DESCRITORES - Metalotioneína. Neoplasias gástricas. Polimorfismo genético. Polimorfismo de fragmento de restrição.

\section{REFERENCES}

1. Nasrabadi NN, Ataee R, Abediankenari S, Shokrzadeh M, Najafi M, Hoseini $\mathrm{SV}$, et al. Expression of MT2 receptor in patients with gastric adenocarcinoma and its relationship with clinicopathological features. J Gastrointest Cancer. 2014;45:54-60.

2. Shokrzadeh M, Ghassemi-Barghi N. Melatonin loading chitosan-tripolyphosphate nanoparticles: Application in attenuating etoposide-induced genotoxicity in HepG2 cells. Pharmacology. 2018;102:74-80.

3. Ghasemi M, Hoseini V, Alizadeh A, Farzad F. Caspase 9 Promoter Polymorphisms in Gastric Cancer, Mazandaran Province. J Mazandaran Univ Med Sci. 2013;23:2-7.

4. Abediankenari S, Shokrzadeh M, Aminjan HH, Nasri N, Alizadeh A. Evaluation of caspase 3 and 9 gene polymorphisms in gastric cancer patients in Mazandaran province: a brief report. Tehran Univ Med J. 2013;71:536-40.

5. Zhen T, Dai S, Li H, Yang Y, Kang L, Shi H, et al. MACC1 promotes carcinogenesis of colorectal cancer via $\beta$-catenin signaling pathway. Oncotarget. 2014;5:3756

6. Ghassemi-Barghi N, Etebari M, Jafarian-Dehkordi A. Protective effect of amifostine on busulfan induced DNA damage in human hepatoma cells. Toxicol Mech Methods. 2017;27:52-7.

7. Shokrzadeh M, Ghassemi-Barghi N. Genoprotective Effects of Amifostine against Mitomycin C-induced Toxicity in Human Hepatoma Cells. Int J Cancer Res Ther 2018;2:1-5

8. Starska K, Krześlak A, Forma E, Olszewski J, Lewy-Trenda I, Osuch-Wójcikiewicz E, et al. Genetic polymorphism of metallothionein $2 \mathrm{~A}$ and risk of laryngeal cancer in a Polish population. Med Oncol. 2014;31:75.

9. Yang C-C, Chen H-I, Chiu Y-W, Tsai C-H, Chuang H-Y. Metallothionein 1A polymorphisms may influence urine uric acid and $\mathrm{N}$-acetyl-beta-D-glucosaminidase (NAG) excretion in chronic lead-exposed workers. Toxicology. 2013;306:68-73.

10. Ganasyam SR, Rao TB, Murthy Y, Jyothy A, Sujatha M. Association of Estrogen Receptor- $\alpha$ Gene \& Metallothionein-1 Gene Polymorphisms in Type 2 Diabetic Women of Andhra Pradesh. Indian J Clin Biochem. 2012;27:69-73.

11. Krześlak A, Forma E, Jóźwiak P, Szymczyk A, Smolarz B, Romanowicz-Makowska $\mathrm{H}$, et al. Metallothionein 2A genetic polymorphisms and risk of ductal breast cancer. Clin Exp Med. 2014;14:107-13.
12. Lei L, Chang X, Rentschler G, Tian L, Zhu G, Chen X, et al. A polymorphism in metallothionein 1A (MT1A) is associated with cadmium-related excretion of urinary beta 2-microglobulin. Toxicol Appl Pharmaco. 2012;265:373-9.

13. Shokrzadeh M, Mohammadpour A, Hoseini V, Abediankenari S, Ghassemi-Barghi N, Tabari YS. Serum cytokine of IL-2, IL-10 and IL-12 levels in patients with stomach adenocarcinoma. Arq Gastroenterol. 2018;55:385-9.

14. Forma E, Krzeslak A, Wilkosz J, Jozwiak P, Szymczyk A, Rozanski W, et al. Metallothionein 2A genetic polymorphisms and risk of prostate cancer in a Polish population. Cancer Genet. 2012;205:432-5.

15. Mohammadi H, Ghassemi-Barghi N, Malakshah O, Ashari S. Pyrethroid exposure and neurotoxicity: a mechanistic approach. Arh Hig Rada Toksikol. 2019;70:74-89.

16. Wong R-H, Huang C-H, Yeh C-B, Lee H-S, Chien M-H, Yang S-F. Effects of metallothionein-1 genetic polymorphism and cigarette smoking on the development of hepatocellular carcinoma. Ann Surg Oncol. 2013;20:2088-95.

17. Chen X, Lei L, Tian L, Zhu G, Jin T. Bone mineral density and polymorphisms in metallothionein $1 \mathrm{~A}$ and $2 \mathrm{~A}$ in a Chinese population exposed to cadmium. Sc Total Environ. 2012;423:12-7.

18. Raudenska M, Gumulec J, Podlaha O, Sztalmachova M, Babula P, Eckschlager $\mathrm{T}$, et al. Metallothionein polymorphisms in pathological processes. Metallomics. 2014;6:55-68.

19. Woods JS, Heyer NJ, Russo JE, Martin MD, Pillai PB, Farin FM. Modification of neurobehavioral effects of mercury by genetic polymorphisms of metallothionein in children. Neurotoxicol Teratol. 2013;39:36-44.

20. Yang C, Wang L, Jiang Q, Wang J, Yue F, Zhang H, et al. The polymorphism in the promoter region of metallothionein 1 is associated with heat tolerance of scallop Argopecten irradians. Gene. 2013;526:429-36.

21. Ghassemi-Barghi N, Varshosaz J, Etebari M, Dehkordi AJ. Role of recombinant human erythropoietin loading chitosan-tripolyphosphate nanoparticles in busulfan-induced genotoxicity: Analysis of DNA fragmentation via comet assay in cultured HepG2 cells. Toxicol In Vitro. 2016;36:46-52

22. Lyn-Cook B, Yan-Sanders Y, Moore S, Taylor S, Word B, Hammons G. Increased levels of NAD (P) H: quinone oxidoreductase 1 (NQO1) in pancreatic tissues from smokers and pancreatic adenocarcinomas: a potential biomarker of early damage in the pancreas. Cell Biol Toxicol. 2006;22:73-80. 
23. Vignal A, Milan D, SanCristobal M, Eggen A. A review on SNP and other types of molecular markers and their use in animal genetics. Evolution. 2002:34:275.

24. Dziegiel P, Pula B, Kobierzycki C, Stasiolek M, Podhorska-Okolow M. Metallothioneins: structure and functions. Metallothioneins in Normal and Cancer Cells: Springer; 2016. p. 3-20.

25. Sekovanić A, Jurasović J, Piasek M, Pašalić D, Orct T, Grgec AS, et al. Metallothionein 2A gene polymorphism and trace elements in mother-newborn pairs in the Croatian population. J Trace Elem Med Biol. 2018;45:163-70.

26. Hattori Y, Naito M, Satoh M, Nakatochi M, Naito H, Kato M, et al. Metallothionein MT2A A-5G polymorphism as a risk factor for chronic kidney disease and diabetes: Cross-sectional and cohort studies. Toxicol Sci. 2016;152:181-93.

27. Zhang Y, Wang Z, Zhong J. Meta-analysis demonstrates that the NAD (P) H: quinone oxidoreductase 1 (NQO1) gene $609 \mathrm{C}>\mathrm{T}$ polymorphism is associated with increased gastric cancer risk in Asians. Genet Mol Res. 2012;11:2328-37.

28. Hu W-G, Hu J-J, Cai W, Zheng M-H, Zang L, Wang Z-T, et al. The NAD (P) H: quinine oxidoreductase 1 (NQO1) gene $609 \mathrm{C}>\mathrm{T}$ polymorphism is associated with gastric cancer risk: evidence from a case-control study and a meta-analysis. Asian Pac J Cancer Prev. 2014;15:2363-7.
29. Kayaaltı Z, Mergen G, Söylemezoğlu T. Effect of metallothionein core promoter region polymorphism on cadmium, zinc and copper levels in autopsy kidney tissues from a Turkish population. Toxicol Appl Pharmacol. 2010;245: 252-5.

30. Deng D, El-Rifai We, Ji J, Zhu B, Trampont P, Li J, et al. Hypermethylation of metallothionein-3 CpG island in gastric carcinoma. Carcinogenesis. 2003; 24:25-9.

31. Starska K, Bryś M, Forma E, Olszewski J, Pietkiewicz P, Lewy-Trenda I, et al. Metallothionein 2A core promoter region genetic polymorphism and its impact on the risk, tumor behavior, and recurrences of sinonasal inverted papilloma (Schneiderian papilloma). Tumor Biol. 2015;36:8559-71.

32. Yan D-W, Fan J-W, Yu Z-h, Li M-x, Wen Y-G, Li D-W, et al. Downregulation of metallothionein $1 \mathrm{~F}$, a putative oncosuppressor, by loss of heterozygosity in colon cancer tissue. Biochim Biophys Acta Mol Basis Dis. 2012;1822: 918-26.

33. Krześlak A, Forma E, Chwatko G, Jóźwiak P, Szymczyk A, Wilkosz J, et al. Effect of metallothionein $2 \mathrm{~A}$ gene polymorphism on allele-specific gene expression and metal content in prostate cancer. Toxicol Appl Pharmacol. 2013;268:278-85. 